\title{
Exploring the effects of input-based instruction on the development of EFL learners' pragmatic proficiency
}

\author{
Ghavamnia, Maedeh \\ University of Isfahan, Iran (ghavamniam@yahoo.com) \\ Eslami-Rasekh, Abbass \\ University of Isfahan, Iran (abbasseslamirasekh@yahoo.com) \\ Vahid Dastjerdi, Hossein \\ University of Isfahan, Iran (느vvahid@yahoo.com)
}

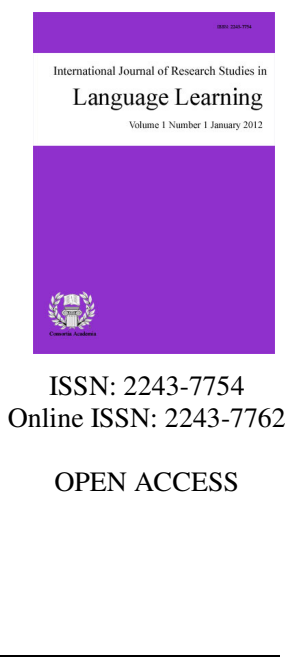

Received: 6 May 2014

\begin{abstract}
The present study evaluates the relative effectiveness of four types of input-based instruction: metapragmatic explanation ( $\mathrm{N}=21)$, form-comparison $(\mathrm{N}=21)$, meaning-focused $(\mathrm{N}=28)$, and input enhancement $(\mathrm{N}=25)$ on the development of the participants' production of pragmatically appropriate requests. The control group $(\mathrm{N}=15)$ did not receive any type of input-based instruction. Over a 16 week course, 110 Iranian undergraduate students majoring in English Translation received input-based instruction with the use of video clips. Treatment group performance was compared to that of a control group on pre-tests and post-tests which took the form of oral and written Discourse Completion Tests (DCTs). The results revealed that the treatment groups significantly improved in the post-test in comparison to the pre-test, outperforming the control group. The findings are discussed with implications for classroom practices and future research.
\end{abstract}

Keywords: EFL context; input-based instruction; noticing hypothesis; interlanguage pragmatics; speech act of request 


\section{Exploring the effects of input-based instruction on the development of EFL learners' pragmatic proficiency}

\section{Introduction}

It is agreed upon that linguistic proficiency does not guarantee communicative efficiency. Since the introduction of communicative competence decades ago, applied linguists started focusing their research on appropriateness rather than being concerned with linguistically appropriate utterances (Simin et al., 2014). Pragmatics, the branch of linguistics which is devoted to examining language use in communication with a main focus on speech acts has aroused the interest of a number of scholars. Pragmatics is a general area within linguistics that seems to cover a wide range of phenomenon, such as deixis, conversational implicature, presuppositions, conversational structure, relevance theory, speech acts theory or politeness theory. From among these areas, the speech act of request is focused on in this study.

The first known study on speech acts was conducted by Austin (1962) and later complemented by Searle (1969). Austin was interested in the number of different things that one could do using language, not just in language as a vehicle for description. Austin categorized speech acts based on five categories: verdictives, exercitives, commissives, behabitives, and expositives. These categories are distinguished based on the types of verbs which appear in utterances. However, Searle's classification of speech acts was based on illocutionary force rather than choice of verb. Searle categories are: assertives, directives, commisives, expressives, and declarations.

Schmidt and Richards (1980) deal with directives claiming that one of the most important uses of language is to get people to do things. Directives include speech acts such as suggestions, requests, and commands. Haverkate (1984) provides a specific definition for exhortative speech acts which are ones in which the speaker wants the hearer to do something. This author distinguishes between impositive and non-impositive directives. The former group includes requesting, pleading, and ordering whereas the latter group includes suggestions. According to Searle (1969) a request is a directive speech act which counts as an attempt to get $\mathrm{H}$ (hearer) to do an act which $\mathrm{S}$ (speaker) wants $\mathrm{H}$ to do, and which $\mathrm{S}$ believes that $\mathrm{H}$ is able to do; and which it is not obvious that $\mathrm{H}$ will do in the normal course of events or of H's own accord' (p. 66).

Results of studies focusing on cross-cultural pragmatics have revealed that learners' performance of speech acts vary according to the learners' first language and inappropriate transfer of strategies from their first language (Bardovi-Harlig, 2001). Due to this, and also the fact that unlike grammatical errors, pragmatic idiosyncrasies may cause communication breakdown with the native speaker, studies in the area of interlanguage pragmatics (ILP) have placed greater emphasis on instruction of L2 pragmatics. In line with this, Rose and Kasper (2001) also suggest three areas that need to be expanded to a great extent including: a) classroom-based interlanguage pragmatics research, to examine the opportunities for developing pragmatics that are offered in language classrooms; b) interlanguage pragmatics research, to prove or disprove whether pragmatic ability develops in classroom setting without explicit instruction; and c) classroom research, to focus on the effects that various approaches to instruction have on pragmatic development.

Regarding pragmatic instruction, Schmidt's Noticing Hypothesis has been adopted by scholars in the field. Schmidt's (1993) noticing hypothesis attends to the role of consciousness in the acquisition of target language knowledge. In order for learners to acquire pragmatic competence, they must pay conscious attention to linguistic forms, functional meanings, and important contextual features. According to Schmidt (2001), since many features of L2 input are likely to be infrequent or non-salient, successful language learning will occur if the learners' attention is intentionally focused. 
Exploring the effects of input-based instruction on the development of EFL learners' pragmatic proficiency

Smith (1993) has defined input enhancement as any pedagogical intervention that is used to make specific target features of the input more salient as an effort to draw learners' attention to these features. He argues that meaning-based activities in the target language alone may not enable learners to detect relevant input features and that some form of input enhancement is needed to make input salient and to encourage noticing. According to Takahashi (2001), research conducted on the role of input enhancement in the development of L2 pragmatics has been fewer in comparison to a rich array of input enhancement research into morphosyntactic features. And hence, it is still not clear which type of input best draws learners' attention and aids noticing.

One technique used to enhance noticing is classroom instruction. From among the varying classroom instruction, interventional treatments have received increasing attention in the field of ILPs and according to Halenko and Jones (2011), most studies demonstrate positive effects on language learners' pragmatic development regardless of linguistic background. The two typical types of pedagogical intervention that have been employed to enhance noticing are those of explicit and implicit instruction. The operationalization of these constructs has been based on the provision of metapragmatic information through description, explanation, or discussion for the explicit group versus relying only on input and practice without metapragmatic discussion for the implicit group (Martinez-Flor, 2004, p. 164). Compared to explicit pragmatic instruction, however, implicit pragmatic instruction has been less adequately conceptualized.

Results of studies obtained by Olshtain and Cohen (1990), Morrow (1995) and Safont (2005) support Schmidt's (1993) Noticing Hypothesis, since they illustrate how making learners notice the specific target language features as a result of instruction promotes learning. In relation to the effect of different teaching approaches to pragmatic learning, the advantage of the planned and explicit teaching condition over the implicit one is reported in House and Kasper (1981), House (1996), Rose and Ng Kwai-Fun (2001), and Takahashi (2001). In Takahashi's (2001) study, for example, input was enhanced through four input conditions which were: explicit teaching, form-comparison, form-search, and meaning-focused conditions. The in the explicit teaching group the participants were provided with metapragmatic information. In the form-comparison group the participants compared their own requests with the ones made by native speakers in the same situations. In the form-search group the participants were asked to find request in the input. The meaning-focused group the participants were asked to answer questions base on the input received. The results revealed that the explicit teaching group outperformed the other groups in the use of target forms. The form-comparison group also had a better performance than the form-search and meaning-focused groups.

Hence, an important issue that has received particular attention concerns the investigation of different pedagogical approaches in teaching pragmatics (Rezvani, Eslami-rasekh, \& Vahid Dastjerdi, 2014). On the one hand, a few studies that have examined how implicit instruction works for pragmatic learning present inconclusive results (e.g. Fukuya et al., 1998; Fukuya \& Clark, 2001; Martinez-Flor, 2004). On the other hand, findings have suggested that explicit instruction (referring to a wide range of classroom techniques which serve to direct learners' attention to form) may produce more effects than implicit instruction (referring to methodological options which allow learners to infer rules without awareness) (Jeon \& Kaya, 2006). However, as warned by Jeon and Kaya (2006), due to a limited number of studies that have examined implicit instruction the findings in this area should be treated with caution. Therefore, in order to understand the relative effectiveness of these two types of pedagogical interventions, further research is certainly needed (Ellis, 2008; Jeon \& Kaya, 2006). VanPatten and Cadierno (1993) argued that instruction should focus on altering how learners perceive and process input rather than changing how learners produce language output. That is, instruction that changes the way input is perceived and processed by learners is more likely to become intake. Ellis (1997) proposed that it is the manipulation of input rather than output that is more likely to result in the integration of intake into learners' implicit/declarative knowledge.

Even though empirical studies have indicated that pragmatic instruction has a positive impact on the speech act production of second and foreign language learners, few studies have examined the implementation of pragmatic instruction using input-based instruction. As thus, in order to add to the findings present in the field of 
pragmatic instruction, and fill the gap by altering the way learners perceive input, this study has operationalized pragmatic instruction through four types of input-based instruction since operationalizing explicit and implicit treatments by only considering the provision or lack of metapragmatic explanation is not enough to show whether learners benefit from these instructional conditions. As such, adopting methodologically sound instructional treatments in ILP research by properly operationalizing both explicit and implicit conditions drawing on SLA research is a must (Rezvani, Eslami-Rasekh, \& Vahid Dastjredi, 2014).

In addition to the operationalization of pragmatic instruction through input-based instruction, the other novelty of this study is that it has tried to remove the major drawback and criticism geared towards DCTs by using both an oral and written production task in order to identify the request strategies used by the participants. The written format may not accurately reflect oral (spoken) language production, and the task is rather artificial, reflecting what a learner believes she would say, rather than demonstrating what she actually says in conversation. Also, Watts (2003) has reported that written DCTs are particularly susceptible to manipulation by informants, resulting in responses that they would never use in actual discourse. On the other hand, Chaudron (2003) suggested that DCTs may not allow learners to sufficiently express their pragmatic competence, particularly in the sense that learners are bound to some extent by the situations presented in the DCT. In order to address such concerns, the written and oral DCTs were utilized for the present in order to encourage the participants to provide realistic responses.

As thus, this study investigated the effect of input-based instruction on the development of EFL learners' production of pragmatically appropriate requests. Hence, the current study aims to answer the following research questions:

$>$ Does input-based instruction - metapragamtic explanation, form-comparison, meaning-focused, and input-enhancement - affect EFL learners' production of pragmatically appropriate requests?

$>$ Is there a significant difference among the EFL learners in the metapragamtic explanation, form-comparison, meaning-focused, and input-enhancement regarding the production of pragmatically appropriate requests? If so, which group(s) outperformed the others?

\section{Method}

\subsection{Participants}

One hundred and ten Iranian female undergraduate students majoring in English Translation, their age ranging from 19 to 23 participated in this study. In order to identify the proficiency level of the participants, they were all asked to complete Test 500 D from the book Nelson English Language Test by W.S. Fowler and Norman Coe. The tests are out of 50 marks and according to the authors of the book those who obtain a score higher than 30 are classified as advanced learners of English. The participants in this study were categorized as intermediate learners of English because their scores on the Nelson test ranged from 23 to 29 with a mean score of 26.8 .

\subsection{Data collection}

In order to identify the development of the participants' production of pragmatically appropriate requests, two types of production tasks in the form of DCTs were administered as pre-tests and post-tests. Basically, a DCT functions to produce a scenario to which a participant or informant must respond. Normally, there is an initial statement outlining the context within which a dialogue occurs. Next, the first line of the dialogue is presented, and the participant is then given an opportunity to respond in the way that she believes most appropriate. Boxer (2002) notes that at this point, DCTs may take one of two forms: open-ended questionnaires simply ask for the subject to supply the appropriate speech act in response to the stimulus (the first line); closed questionnaires extract a speech act from the subject, but then follow the blank line with a reply from the first 
Exploring the effects of input-based instruction on the development of EFL learners' pragmatic proficiency speaker, so that the response must take into account not only the opening statement, but also the reply to follow (p. 15). Recognizing the limitations of DCT tasks is essential (Beebe \& Cummings, 1996; Kasper \& Roever, 2005). Among the most common criticisms of the written DCT are that the written format may not accurately reflect oral (spoken) language production, and that the task is rather artificial, reflecting what a learner believes she would say, rather than demonstrating what she actually says in conversation. Also, Watts (2003) has reported that written DCTs are particularly disposed to manipulation by informants, resulting in responses that they would never use in actual discourse. On the other hand, Chaudron (2003) suggested that DCTs may not allow learners to sufficiently express their pragmatic competence, particularly in the sense that learners are bound to some extent by the situations offered in the DCT. In order to address such concerns, both an oral (phone task) and written (email task) DCT were utilized for the present study which included a variety of academically oriented contexts and every effort was made to encourage the participants to provide realistic responses.

The pre-tests contained 4 situations and the post-tests contained 4 situations. The participants were asked to provide their responses either orally by leaving a message on an answering machine or through sending an email. On the phone task, the participants were asked to read two situations in which they had to make a) a request to a friend at university and b) a request to a professor at university. For each situation, they had to dial the phone number provided by the researcher and leave a message on the friend/professor's answering machine making a request. The same thing had to be done on the email task, with the difference that this time they had to send an e-mail to a friend or a professor, making a request based on the situations on the DCT. The procedures the participants had to go through on the post-tests were exactly the same as the pre-tests, the only difference being the situations.

\subsection{Input-based instruction}

Regarding the speech act of requesting, the typology of modifiers proposed by Soler, Jorda, and Martinez-Flor (n.d.) were used in this study. The modifiers adopted from the typology can be found in the following table (Table 1).

\section{Table 1}

Typology of Modifiers

\begin{tabular}{|c|c|}
\hline \multirow{2}{*}{ Internal modification } & Opener: Do you think ... \\
\hline & $\begin{array}{l}\text { Fillers } \longrightarrow \quad \text { Attention getters: Excuse me, } \\
\text { Hey, Look, Mr., Mrs., Madam ... }\end{array}$ \\
\hline \multirow{5}{*}{ External modification } & Preparators: May I ask you a favor? \\
\hline & Grounders: I forgot my book ... \\
\hline & $\begin{array}{r}\text { Disarmer: I know you are really busy ... } \\
\text { I hate to ask you but ... }\end{array}$ \\
\hline & Promise of reward: \\
\hline & Please: \\
\hline
\end{tabular}

Five intact classes were selected for the purpose of this investigation. The instructor of all the five classes was the first author of this study. The students in the treatment groups received some form of input-based instruction on the pragmatic features under investigation while the students in the control group were only instructed on the course material. The courses the participants were enrolled in differed from one group to the other. However, all the participants in the experimental groups engaged in the same tasks and activities when it came to the treatment. The only difference among the four experimental groups was in the way the L2 pragmatic input was enhanced and delivered to them. 
The pragmatic features under investigation were instructed using a total number of 6 video clips which the researcher downloaded from YouTube. The video clips included situations in which a native speaker of English made a request to a friend or a professor. The criterion for the selection of the video clips was that the requests made were part of the target forms under investigation in this study.

The participants in this study were all enrolled in a 16 session course that lasted 16 weeks. Each session lasted 90 minutes in which the last 30 minutes was devoted to research purposes. On the first session, the participants in all five groups were asked to complete the Nelson test. On the second session, the participants were handed the pre-tests and asked to complete the phone and e-mail tasks prior to the third session. The actual treatment for the four experimental groups was implemented into six sessions (sessions: 4, 6, 8, 10,12,14) of the course. In other words, target forms were instructed every other session. The participants did not receive any instruction on the $15^{\text {th }}$ and $16^{\text {th }}$ sessions. At the end of the $16^{\text {th }}$ session, the post-tests were handed to the participants and they were asked to complete the phone and e-mail tasks prior to the end of the week.

The four experimental groups first watched a video clip. Then, depending on the type of input-based instruction they were to receive, they would take part in a series of activities.

In the first group ( $\mathrm{N}=21)$ input was enhanced through metapragmatic explanation. The learners first watched a video clip and then the students were asked to answer a set of awareness-raising questions based on the video clip they had watched. Then, the transcript of the video clip was handed to the participants and each student read over the transcript with a partner. Finally, they received explicit instruction on the target forms and metapragmatic information about the appropriate use of the target forms.

In the second group ( $\mathrm{N}=21)$ input was enhanced through form-comparison. In this group the participants first received the transcript of the video clip with this difference that the requests made were omitted. At first, the participants were asked to fill in the blanks with a pragmatically appropriate and grammatically accurate request. After the participants filled in the blanks with an appropriate form of the speech act, the instructor played the video clip for the class. Then they received the complete transcript of the video clip and each participant was asked to compare her own speech act form with the one on the video clip transcript. They were also asked to write down any differences and/or similarities they spotted between their own responses as non-native speakers of English and the responses of the interlocutors on the video clips as native speakers of English.

In the third group ( $\mathrm{N}=28$ ) input was enhanced through meaning-focused instruction. The participants in this group first watched a video clip. Then, they were given the transcript of the video clip they had watched with a number of comprehension questions. They were asked to read the transcript and answer the comprehension questions.

In the fourth group ( $\mathrm{N}=25)$ the target forms were typographically enhanced through providing the subtitles of the video clips in bold. After having watched the video clip, the participants in this group received the transcript of the video clip with the target forms highlighted. They were asked to read over the transcript with a partner in order to be able to give a summary to the class. Then, the instructor asked the students to provide oral summaries for the class.

The control group ( $\mathrm{N}=15)$ just watched the video clips as an extra activity with an intent of becoming more familiar with English native speakers' accent.

\subsection{Data analysis}

In order to analyze the data, the participants' messages on the answering machine were transcribed. A total number of 880 responses (110 participants $\times 2$ tests $\times 2$ production tasks $\times 2$ situations) were retrieved from the participants' responses on the phone and e-mail tasks. The scoring system used in this study - adopted from Martinez-Flor's (2004) study - is illustrated in Table 2. 
Table 2

Scoring for Appropriateness Level

\begin{tabular}{lc}
\hline Appropriateness level & Score \\
\hline Inappropriate head act & 0 \\
Appropriate head act & 1 \\
Appropriate head act + appropriate modifier for requests & 1.5 \\
\hline
\end{tabular}

The participants' responses were corrected twice, once by the first author and the second time by the second author of this study. The inter-rater reliability was estimated and Cronbach $\alpha$ was 0.89 . Only when participants employed the target head acts in appropriate contexts were they awarded points. The following examples taken from the participants replies show how the scores for pragmatic appropriateness assigned.

Example (1): I've decided to take part in the M.A. entrance exam. I don't have enough time to study. Can you introduce to me the books that should be prioritized?

In this situation a request had been made to a professor. As thus, the request head act has not been used appropriately. Hence, even though the participant has provided a grounder for the request, the score given to this response is 0 since the head act was inappropriately used.

Example (2): Hello, my friend. I haven't been in the mood to take notes. Can you lend me your notes so that I can get a copy of them? Good-bye.

In this situation, a request was made to a friend. The respondent has provided a reason (grounder) for her request. The participant has also used an appropriate head act for making the request (can). As thus, the mark given to this response was 1.5 .

\section{Results and Discussion}

In order to answer the first research question, the mean scores gained by the five groups on the pre-tests and post-tests were estimated using the SPSS software.

\section{Table 3}

Mean Scores Gained by the Five Groups on the Pre-tests and Post-tests

\begin{tabular}{lllccccc}
\hline \multirow{2}{*}{ Tasks } & \multicolumn{1}{c}{ Groups } & \multicolumn{2}{c}{ Pre-test } & \multicolumn{2}{c}{ Post-test } & \multicolumn{2}{c}{$\begin{array}{c}\text { Pre-test- } \\
\text { Post-test gain }\end{array}$} \\
& & & $\mathrm{N}$ & $\mathrm{SD}$ & $\mathrm{M}$ & $\mathrm{SD}$ & \\
\hline Phone & Metapragmatic explanation & 21 & 1.3095 & .46033 & 2.5000 & .50000 & 1.19 \\
& Form-comparison & 21 & .9524 & .56800 & 2.2143 & .48917 & 1.26 \\
& Input-enhanced & 25 & 1.1200 & .41533 & 1.3400 & .37417 & 0.22 \\
& Meaning-focused & 28 & .8036 & .49701 & 1.4464 & .31445 & 0.64 \\
& Control & 15 & .9667 & .61140 & .9333 & .70373 & -0.03 \\
\hline E-mail & Metapragmatic explanation & 21 & 1.5238 & .48673 & 2.6667 & .39791 & 1.14 \\
& Form-comparison & 21 & .9524 & .35017 & 2.1667 & .42817 & 1.21 \\
& Input-enhanced & 25 & 1.1400 & .46815 & 1.6200 & .50580 & 0.48 \\
& Meaning-focused & 28 & .7321 & .55247 & 1.4643 & .50787 & 0.73 \\
& Control & 15 & .9333 & .70373 & 1.2000 & .90238 & 0.27 \\
\hline
\end{tabular}

By comparing the mean scores on the pre-tests and post-tests (Table 3), it was clear that the treatment groups which received input-based instruction had improvement in their production of pragmatically appropriate 
Ghavamnia, M., Eslami-Rasekh, A., \& Vahid Dastjerdi, H.

requests on both the phone and e-mail tasks. In addition, figures 1 and 2 graphically show the improvement of the participants' production of pragmatically appropriate requests on the phone and email tasks.

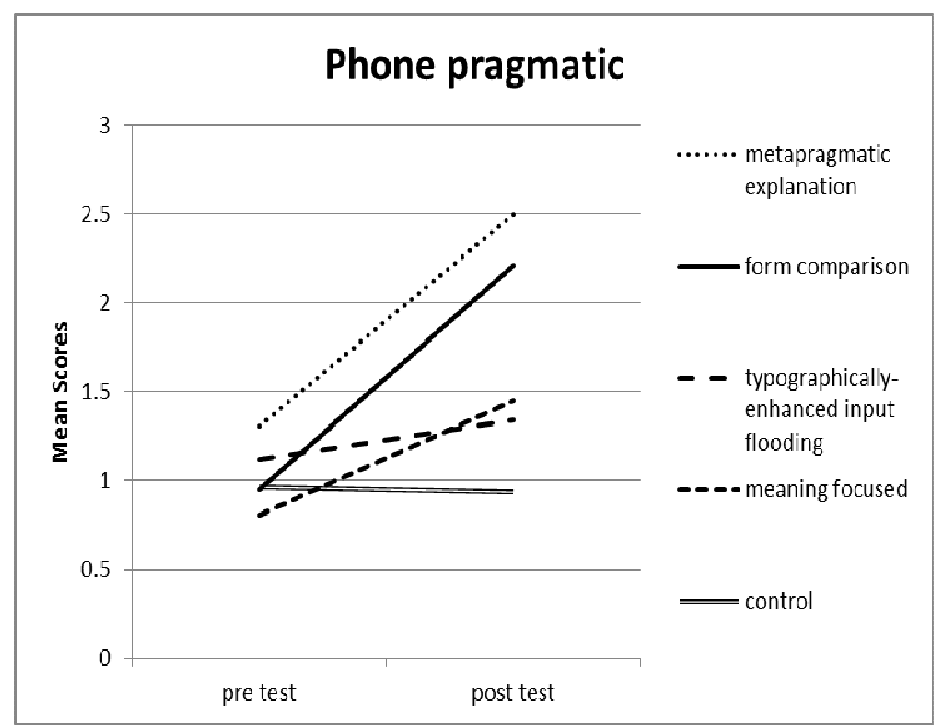

Figure 1. Scores gained by the five groups on the pre-tests and post-tests

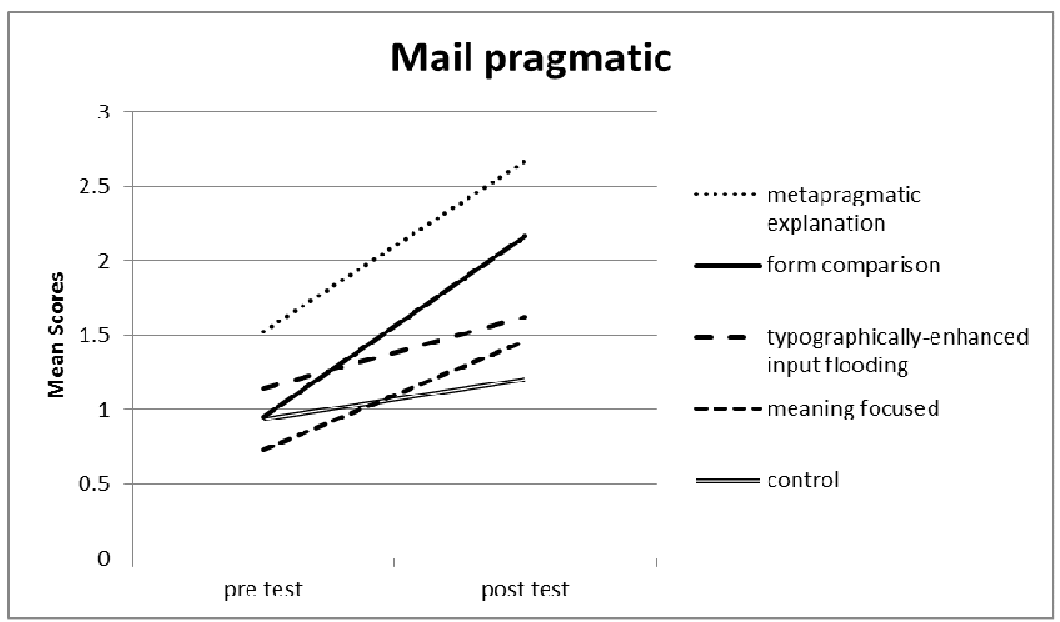

Figure 2. Scores gained by the five groups on the pre-tests and post-tests

In order to answer the second research question, a mixed between-within subjects ANOVA was run (Table 4). Before running the aforementioned statistical tool, the normality was tested. The Shapiro-Wilk test for normality was examined at the significance value of .01 . The significance values of the pre-test and post-test of the five groups were greater than .01 . As thus, the sample was not significantly deviated from normality. Following that the Homogeneity of Covariance was examined by adopting the Box's Test. The result was tested at the significance value of .01 and the covariance was homogeneous.

Regarding the performance of the participants on the phone task, first the interaction effect was examined. The result of "TimexGroup" was significant, $F(4,105)=42.574, p<.001$. As thus, there is an interaction effect. Hence, it could be concluded that across time the effect of the group is changing. Next, the main effect was examined. The result of the main effect of "Time" was significant, $\mathrm{F}(1,105)=302.199, p<.001, \eta p^{2}=.74$. There was also a significant main effect related to "Group", $\mathrm{F}(4,105)=14.851, p<.001, \eta p^{2}=.36$.

There were no significant differences among the five groups on the pre-test $[\mathrm{F}(4,105)=3.397, p>.01]$; However, the four treatment groups displayed improvement from the pre-test to the post-test $(p<.01)$, whereas 
Exploring the effects of input-based instruction on the development of EFL learners' pragmatic proficiency the control group did not $(p>.01)$.

\section{Table 4}

Mixed Between-Within Subjects ANOVA

\begin{tabular}{|c|c|c|c|c|c|c|}
\hline Source & SS & df & MS & $\mathrm{F}$ & $\mathrm{p}$ & $\eta p^{2}$ \\
\hline \multicolumn{7}{|l|}{ Phone pragmatic } \\
\hline Time & 22.664 & 1 & 22.664 & 302.199 & $.000^{*}$ & .742 \\
\hline Group×Time & 12.772 & 4 & 3.193 & 42.574 & $.000 *$ & .619 \\
\hline Error & 7.875 & 105 & .075 & & & \\
\hline \multicolumn{7}{|c|}{ Between-group } \\
\hline \multirow{2}{*}{$\begin{array}{l}\text { Group } \\
\text { Error }\end{array}$} & 23.539 & 4 & 5.885 & 14.851 & $.000^{*}$ & .361 \\
\hline & 41.607 & 105 & .396 & & & \\
\hline \multicolumn{7}{|l|}{ E-mail pragmatic } \\
\hline Time & 30.962 & 1 & 30.962 & 387.687 & $.000^{*}$ & .787 \\
\hline Group $\times$ Time & 6.496 & 4 & 1.624 & 20.335 & $.000^{*}$ & .437 \\
\hline Error & 8.386 & 105 & .080 & & & \\
\hline \multicolumn{7}{|c|}{ Between-group } \\
\hline \multirow{2}{*}{$\begin{array}{l}\text { Group } \\
\text { Error }\end{array}$} & 29.532 & 4 & 7.383 & 15.328 & $.000^{*}$ & .369 \\
\hline & 50.577 & 105 & .482 & & & \\
\hline
\end{tabular}

Post hoc LSD analyses conducted on the post-test for the main effect of groups revealed that there was no significant difference between the metapragmatic explanation and the form-comparison groups $(p>.01)$. These two groups had a significantly better performance in comparison to the input-enhanced, meaning-focused, and control groups. No significant difference existed among the input-enhanced and meaning-focused groups regarding the production of pragmatically appropriate requests on the phone task $(p>.01)$. However, they performed significantly better than the control group $(p<.01)$.

In relation to the participants' performance on the e-mail task, the interaction effect was examined. The result of "TimexGroup" was significant, $F(4,105)=20.335, p<.001$. Hence, there was an interaction effect. It could be stated that across time the effect of the group was changing. Then, the main effect was examined. The result of the main effect of "Time" was significant, $\mathrm{F}(1,105)=387.687, p<.001, \eta p^{2}=.78$. There was also a significant main effect in "Group", $\mathrm{F}(4,105)=15.328, p<.001, \eta p^{2}=.37$.

There were significant differences among the five groups on the pre-test $[\mathrm{F}(4,105)=7.742, p<.01]$; as thus, the differences between the pre-test and post-test were compared among the five groups. There were significant differences among the five groups on the pre-test post-test gain $[\mathrm{F}(4,105)=20.335, p<.01]$.

Post hoc LSD analyses conducted on the pre-test post-test gain showed that there was no significant difference between the metapragmatic explanation and form-comparison groups $(p>.01)$. These two groups, however, had a better performance in comparison to the input-enhanced, meaning-focused and control groups ( $p$ $<.01)$. There was no significant difference between the meaning-focused and input-enhanced groups $(p>.01)$. The meaning-focused group performed significantly better than the control group $(p<.01)$. However, there was no significant difference between the input-enhanced and control groups $(p>.01)$.

\section{Conclusion}

The purpose of the present study was to investigate the relative efficacy of four types of input- based instruction - metapragmatic explanation, form-comparison, meaning-focused, and input-enhanced - on a group of Iranian EFL learners' production of requests. In addition to dealing with instructional effects, the degree of effectiveness was also considered (Rose \& Kasper, 2002). 
Some studies have examined the effect of explicit instruction (e.g. Bacelar Da Silva, 2003; Liddicoat \& Crozet, 2001; Salazar, 2003) on various pragmatic featuers. These studies strongly suggest that metapragmatic information is effective regardless of the participants' proficiency level. Other studies conducted in the field of pragmatic instruction have demonstrated that explicit instruction is more effective than implicit instruction (e.g., House, 1996; Pearson, 2005; Takahashi, 2001; Tateyama et al., 1997). It has also been indicated that explicit instruction in combination with some sort of input enhancement could be even more effective (e.g. Kubota, 1995; Pearson, 1998; Takahashi, 2001; Tateyama et al., 1997). The findings of this study show that not only explicit instruction, but also enhanced input alone without some form of explicit instruction (e.g. metapragmatic explanation, metapragmatic discussion, or awareness-raising activities) could be beneficial for the development of pragmatic features, in this case being the speech act of requests. The reason enhanced input alone could result in pragmatic development might be related to the fact that while the main focus is on meaning, the learners process the input in order to get to the meaning. As thus, the pragmatic features present in the input are consciously or sub-consciously attended to. Overall, based on the findings, this study claims that any type of input-based instruction - ranging from highly enhanced input (metapragmatic explanation) to very low enhanced input (typographically enhanced input - could result in significant improvement in the L2 learners' pragmatic competence.

From the perspective of language pedagogy, the findings of this study provide empirical support for the instruction of pragmatics in the EFL classrooms. Due to the fact that unlike grammatical errors, pragmatic idiosyncrasies may cause communication breakdown, instruction of pragmatic features should gain importance in the EFL context. Although there are some problems facing the EFL context such as large classes, limited contact hours and little opportunity for intercultural communication, this study has shown that form-comparison tasks could be implemented into the agenda in order to prevent the EFL learners from producing pragmatically inappropriate statements. Just as results obtained by Olshtain and Cohen (1990), Morrow (1995), and Safont (2005) in support of Schmidt's (1993) noticing hypothesis show, making learners notice the specific target language features through instruction promotes learning.

\subsection{Pedagogical implications}

In regards to the findings of the present investigation, the following pedagogical implications were made. In the first place, pragmatic instruction should find a place in the EFL context since without instruction EFL learners are not able to use pragmatic features of the target language appropriately. The second implication worth emphasis is that in contrast to time limitations which most EFL instructors believe to be the most apparent reason for putting aside pragmatic instruction; this study has shown that focusing on pragmatic features does not take up much of the class time. In addition, the time devoted to pragmatic instruction yields constructive results. Finally, it can be claimed that various input-based instructional tasks (e.g. form-comparison, meaning-focused instruction, and input-enhancement) which are much more motivating could take the place of pragmatic instruction adopting metapragmatic explanation.

\section{References:}

Austin, J. L. (1962). How to do things with words. Cambridge: Harvard University Press.

Bardovi-Harlig, K. (2001). Evaluating the empirical evidence: grounds for instruction in pragmatics. In: K.R. Rose \& G. Kasper (Eds.), Pragmatics in language teaching (pp. 13-32). Cambridge: Cambridge University Press. http://dx.doi.org/10.1017/CBO9781139524797.005

Beebe, L., \& Cummings, M. (1996). Natural speech act data versus written questionnaire data: How data collection method affects speech act performance. In S. Gass \& J. Neu (Eds.), Speech acts across cultures (pp. 65-86). Berlin: Mouton de Gruyter.

Boxer, D. (2002). Applying sociolinguistics: Domains and face-to-face interaction. Philadelphia: John

Benjamins Publishing Company. http://dx.doi.org/10.1075/impact.15

Chaudron, C. (2003). Data collection in SLA research. In C. J. Doughty \& M. H. Long (Eds.), The handbook of 
Exploring the effects of input-based instruction on the development of EFL learners' pragmatic proficiency

second language acquisition (pp. 762-828). Malden, MA: Blackwell.

http://dx.doi.org/10.1002/9780470756492.ch22

Ellis, R. (1997). SLA research and language teaching. Oxford: Oxford University Press.

Ellis, R. (2008). The study of second language acquisition. Oxford University Press, Oxford.

Fukuya, Y., \& Clark, M. (2001). A comparison of input enhancement and explicit instruction of mitigators. In L.

Bouton (Ed.), Pragmatics and language learning, (pp. 111-130). University of Illinois at Urbana-Champaign: IL.

Fukuya, Y., Reeve, M., Gisi, J., \& Christiansin, M. (1998). Does focus on form work for sociopragmatics? Paper presented at the $12^{\text {th }}$ Annual International Conference on Pragmatics and Language Learning. Urbana, IL: University of Illinois at Urbana-Champaign.

Halenko, N., \& Jones, C. (2011). Teaching pragmatic awareness of spoken requests to Chinese EAP learners in the UK: Is explicit instruction effective? System, 39, 240-250. http://dx.doi.org/10.1016/j.system.2011.05.003

Haverkate, H. (1984). Speech acts, speakers and hearers: Pragmatics and beyond. Amsterdam: John Benjamin Publishing Company. http://dx.doi.org/10.1075/pb.v.4

House, J. (1996). Developing pragmatic fluency in English as a foreign language: routines and metapragmatic awareness. Studies in Second Language Acquisition, 18(2), 225-252. http://dx.doi.org/10.1017/S0272263100014893

House, J., \& Kasper, G. (1981). Politeness markers in English and German. In F. Coulmas (Ed.), Conversational routine (pp. 157-185). The Hague: Mouton de Gruyter.

Jeon, E. H., \& Kaya, T. (2006). Effects of L2 instruction on interlanguage pragmatic development: A meta-analysis. In J. M. Norris \& L. Ortega (Eds.), Synthesizing research on language learning and teaching (pp. 165-211). John Benjamins Publishing Company. http://dx.doi.org/10.1075/1llt.13.10jeo

Kasper, G., \& Roever, C. (2005). Pragmatics in second language learning. In E. Hinkel (Ed.), Handbook of research in second language teaching and learning (pp. 317-334). Mahwah, NJ: Lawrence Erlbaum Associates.

Kubota, M. (1995). Teachability of conversational implicature to Japanese EFL learners. IRLT Bulletin, 9, $35-67$. Liddicoat, A. J., \& Crozet, C. (2001). Acquiring French international norms through instruction. In K.R. Rose \& G. Kasper (Eds.), Pragmatics in language teaching (pp. 125-144). Cambridge: Cambridge University Press. http://dx.doi.org/10.1017/CBO9781139524797.012

Martinez-Flor, A. (2004). The effect of instruction on the development of pragmatic competence in the English as a foreign language context: A study based on suggestions. Unpublished doctoral dissertation, Universitat Jaume I, Spain.

Morrow, C.K. (1995). The pragmatic effects of instruction on ESL learners' production of complaint and refusal speech acts. Unpublished doctoral dissertation, Buffalo State University, New York.

Olshtain, E., \& Cohen, A.D. (1990). The learning of complex speech act behavior. TESL Canada Journal, 7 , $45-65$.

Pearson, L. (1998). Spanish L2 pragmatics: The effects of metapragmatic discussion. Paper presented at Second Language Research Forum '98, University of Hawaii, Manoa.

Rezvani, E., Eslami-Rasekh, A., \& Vahid Dastjerdi, H. (2014). Investigating the effects of explicit and implicit instruction on Iranian EFL learners' pragmatic development: Speech act of requests and suggestions in focus. International Journal of Research Studies in Language Learning. In press. http://dx.doi.org/10.5861/ijrsll.2014.799

Rose, K., \& Kasper, G. (2001). Pragmatics in language teaching. Cambridge: Cambridge University Press. http://dx.doi.org/10.1017/CBO9781139524797

Rose, K., \& Ng Kwai-fun, C. (2001). Inductive and deductive teaching of compliments and compliment responses. In: R. Kenneth \& G. Kasper (Eds.), Pragmatics in language teaching (pp.145-170). New York: Cambridge University Press.

Safont, M.P. (2005). Third language learners' pragmatic production and awareness. Multilingual Matters: Clevedon. 
Ghavamnia, M., Eslami-Rasekh, A., \& Vahid Dastjerdi, H.

Salazar, P. (2003). Pragmatic instruction in the EFL context. In A. Martinez-Flor, E. Uso, \& A. Fernandez (Eds.), Pragmatic competence in foreign language teaching (pp. 233-246). Castello: Servei de publicacions de la universitat Jaume I.

Schmidt, R. (1993). Consciousness, learning and interlanguage pragmatics. In G. Kasper \& S. Blum-Kulka (Eds.), Interlanguage pragmatics (pp. 21-42). New York: Oxford University Press.

Schmidt, R. (2001). Attention. In P. Robinson (Ed.), Cognition and second language instruction (pp. 3-33). New York: Cambridge University Press. http://dx.doi.org/10.1017/CBO9781139524780.003

Schmidt, R., \& Richards, J. (1980). Speech acts and second language learning. Applied Linguistics, 1(2), 127-157. http://dx.doi.org/10.1093/applin/1.2.129

Searle, J. (1969). Speech acts: An essay in the philosophy of language. London: Cambridge University Press. http://dx.doi.org/10.1017/CBO9781139173438

Simin, S., Eslmai, Z. R., Eslami-Rasekh, A., \& Ketabi, S. (2014). The effect of explicit teaching of apologies on Persian EFL learners' performance: When e-communication helps. International Journal of Research Studies in Language Learning, 3(4), 71-84. http://dx.doi.org/10.5861/ijrsll.2014.661

Smith, S. (1993). Input enhancement in instructed SLA: Theoretical bases. Studies in Second Language Acquisition, 15, 165-179. http://dx.doi.org/10.1017/S0272263100011943

Takahashi, S. (2001). The role of input enhancement in developing pragmatic competence. In K. R. Rose \& G. Kasper (Eds.), Pragmatics in language teaching (pp.171-199). Cambridge: Cambridge University Press. http://dx.doi.org/10.1017/CBO9781139524797.014

Tateyama, Y., Kasper, G., Mui, L., Tay, H., \& Thananart, O. (1997). Explicit and implicit teaching of pragmatic routines. In L. Bouton (Ed.), Pragmatics and language learning (pp. 163-178). University of Illinois: Urbana-Champaign, IL.

VanPatten, B., \& Cadierno, T. (1993). Explicit instruction and input processing. Studies in Second Language Acquisition, 15, 225-243. http://dx.doi.org/10.1017/S0272263100011979

Watts, R. J. (2003). Politeness. Cambridge: Cambridge University Press. http://dx.doi.org/10.1017/CBO9780511615184 
Appendix A: Pre-tests

You are going to read two different situations. Imagine that you are in those situations. Make a telephone call in English after reading them and leave a message in English making a request. (The phone number was provided by the instructor)

You have decided to take part in the M.A. entrance exam which will be held in a couple of months from now. You have found the references that you must cover for the exam but you don't know which ones are of greater importance. Since you don't have time to cover all the books, you want to call your professor and ask her to introduce to you the books that should be given priority.

The midterm exams are coming up. You've been attending class on a regular basis. However, you haven't been in the mood to take notes. You want to call your friend and ask her to lend you her notes so you could get a copy of them for yourself.

You are going to read two different situations. Imagine that you are in those situations. Write and send an email in English making a request to the e-mail address provided by the instructor.

Your midterm exam will be held in two week from now. However, because of some personal problems you will not be able to attend that session. You want to ask the professor to change the date of the exam.

You are an instructor at an English Institute. Something important has come up for you and you can't make class tomorrow. You'd like you friend to cover for you. Send your friend an email and ask her to attend class instead of you. 
Appendix B: Post-tests

You are going to read two different situations. Imagine that you are in those situations. Make a telephone call in English after reading them and leave a message in English making a request.

You've been having trouble in writing an article which is due as a class project. You want to call your professor and ask her to help you on writing the article.

You want to ask your friend to give you a ride to the university since you slept in and you have a really important exam first thing in the morning.

You are going to read two different situations. Imagine that you are in those situations. Write and send an email in English making a request to the e-mail address provided by the instructor.

You feel the mark that the professor has given you is not fair. You want to ask the professor to reconsider your mark and take into consideration your class participation.

You are really weak in English and you have to hand in a project to your professor no later than next week. You want to ask your friend to help you on your project since she's really good at English. 